\title{
History of Islamic Medicine
}

The history of Islamic medicine is a subject of which most Muslim physicans have very little knowledge. I am a good example. I did my basic medical education in India, where I received an MBBS, the undergraduate degree equivalent 10 an MD in the United States. Thereafter, I went to England for surgical training and got an FRCS, the fellowship of the esteemed College of Surgeons of England. Then I came to the United States to do additional training in cardiac surgery and was certified by the American College of Surgeons. All during this educational career, not once did I leam anything about the brilliant history of Islamic medicine, which is that Islamic medicine was the only scientific medicine that existed in the world for almost 1,000 years prior to the advent of modern medicine. Was this as a result of my ignorance; lack of inquisitiveness, perhaps; or was it because the modern medical education system willfully neglects and ignores this illustrious period of medicine so that fewer and fewer people are knowledgeable about the subject? I feel that it is because of the system of education in the present day secularized medical schools that the Islamic nations totally ignore the scintillating history of our past achieverments in their curricula.

It was an Indian sage who said: "Those that do not learn from history are condemed to repeat it." Nothing can be farther from the truth. Is it then not necessary for us to do something about this gap in our acquisition of knowledge at least for the future generations of Muslims? I think it is imperative that all medical schools in all Muslim countries should (as soon as possible) include a full course of the history of Islamic medicine in their curricula. Only by doing this will we Muslims be able to educate our future gencrations about this historical period. Were it not for the contributions of the great Muslim physicians during the so called "medieval period," modern medicine would not have come into existence in its present form. Thus, many of the fundamentals of medical sciences that were laid during this era would never have come about.

Once I became a student of this subject I have found, among other things, the following:

- Very few scholars of this subject are alive today.

- Those few who are knowledgeable are most often Orientalists and non-Muslinss and, thus, look upon the subject with a different perspective.

- Only a handfull of Muslims have written anything about Islamic medicine in recent times.
There are no authoritative books on the subject in English to which an inquisitive student can refer or study from.

One of the reasons for the creation of the International Institute of Islamic Medicine (IIIM) by the Islamic Medical Association was to foster this idea and try and promote it so that Muslims, and especially Muslim physicians, become knowledgeable about this neglected subject.

The institute has been working towards this aim for the last three years. One of the first undertakings was to hold the "First International Seminar and Conference on Islamic Medicine in North America" in Orlando, Florida, on April 14-17, 1995. This conference was a great success and was attended by about 300 delegates from all over the world. The discussions were lively and extremely informative and created the spirit to revive the traditions of Islamic medicine. Thus, we did learn the first lesson of history, which was to learn from history and apply it to the future. There is no better lesson to learn. Great Islamic scholars of the history of Islamic medicine -- like Hakim Mohammed Said and Dr. Hossein Nasr -- had one clear message to give: We should not only revive the traditions of Islamic medicine, but inculcate them in everyday practice. Although this seems like a dream, it can be accomplished. We are greatly pleased that we are now able to present you with part of the proceedings of this conference in this issue of JIMA, which will become a landmark in the history of IMA and IIIM. The remainder of the proceedings will be in the October 1996 JIMA. In this issue you will find great and eminent scholars lucidilly and succinctly discussing their views about this subject. I am sure you will find their philosophical aspects extremely appealing and informative.

You also will be pleased to know that IMA and IIIM are proudly offering a didactic course in the history of Islamic medicine on May 9-11, 1997, in Florida. For details of this, please read the announcement included in this issue. This is going to be fascinating and informative, but the space is limited. Make reservations early so that you do not miss out on this rare opportunity to attend. Praise be to Allāh [SWT].

Busain F. Nagamia, MD Chairman

International Institute of Islamic Medicine (IIIM) Past President Islamic Medical Association of North America (IMA) 